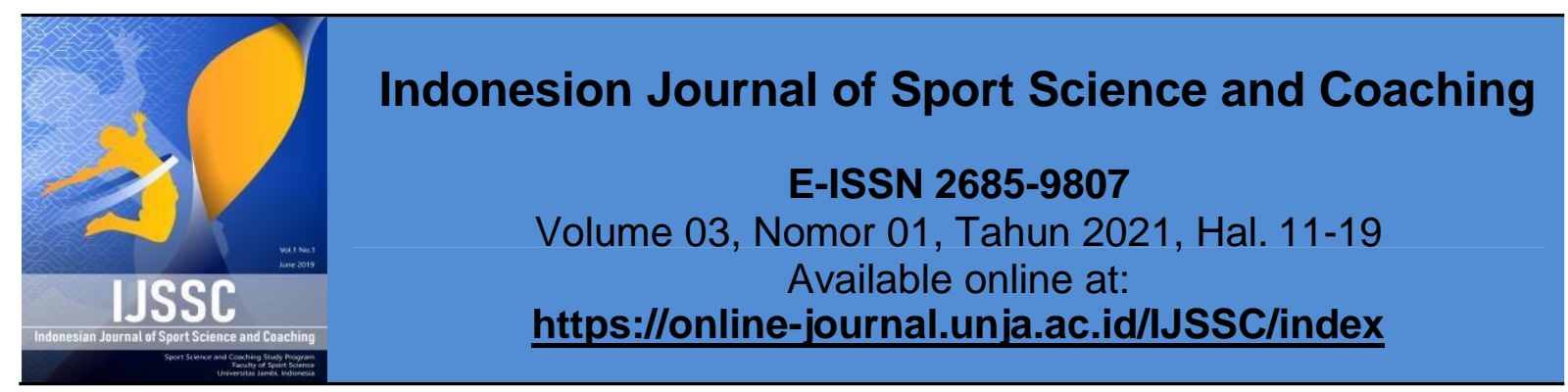

Research Article

OPEN $\bigcirc$ ACCESS

\title{
Pengaruh Kecepatan Lari, Power Otot Tungkai dan Latihan Menggunakan Box Jump Terhadap Hasil Lompat Jauh Siswa Kelas X SMA Negeri 9 Batanghari
}

\section{(The Effect of Running Speed, Leg Muscle Power and Exercise Using Box Jump on the Long Jump Results of Class X Students of SMA Negeri 9 Batanghari)}

\author{
Kasihatun ${ }^{1}$, Sukendro ${ }^{2}$ \\ Magister Teknologi Pendidikan, Universitas Jambi, Indonesia ${ }^{12}$ \\ Corresponding author : kasiha976@gmail.com
}

\begin{tabular}{|c|c|}
\hline Informasi Artikel & ABSTRACT \\
\hline Submit: $12-03-2021$ & $\begin{array}{l}\text { The long jump results achieved by the students were still in the } \\
\text { poor category because there were some students who could not } \\
\text { meet the jump result standards that had been set for the amount. } \\
\text { Researchers need some precise steps to be able to improve } \\
\text { students' long jump results. The purpose of this study was to } \\
\text { determine the effect of running speed with long jump results, to } \\
\text { determine the effect of leg muscle power on long jump results and } \\
\text { the effect of variations in exercise using box jump media on long } \\
\text { jump results of SMA Negeri } 9 \text { Batanghari students. This research } \\
\text { was conducted using quasi-experimental research or quasi } \\
\text { experiment. Where in this study, will be applied to the One Group } \\
\text { Pre test Post test design. The population in this study was } 100 \\
\text { people, who were then used as samples of } 26 \text { people, by means of } \\
\text { sampling through quota sampling and purposive sampling. The } \\
\text { samples were students with a height of } \pm 165 \text { cm. The results of the } \\
\text { research that have been conducted by researchers mean that from } \\
\text { the initial test is } 3,629 \text { and the average for the final test is 3,945. } \\
\text { The pre-test standard deviation is } 0.8541 \text { and the post-test standard } \\
\text { deviation is } 0.6141 \text {. Hypothesis testing in this study used t-test, } \\
\text { where t-count was } 7,191 \text { and t-table was 2,060 with } \alpha=0.05 \text {. } \\
\text { Comparison of prices between t-count and percentile values from } \\
\text { the distribution table obtained t-count (7.19)> t-table (2.060). So } \\
\text { that HO is rejected and Ha is accepted. Based on the results of } \\
\text { research and discussion, where t-count (7.19)> t-table (2.060), it } \\
\text { can be concluded that there is a significant influence between } \\
\text { running speed, leg muscle power and training using box jump on } \\
\text { jumping results. far away from class X students at SMA Negeri } 9 \\
\text { Batanghari } \\
\text { Keywords: Running Speed, Leg Muscle Power, Box Jump, Long } \\
\text { Jump }\end{array}$ \\
\hline
\end{tabular}




\begin{tabular}{|c|c|}
\hline Penerbit & ABSTRAK \\
\hline $\begin{array}{l}\text { Jurusan Pendidikan } \\
\text { Olahraga dan } \\
\text { Kepelatihan FKIP } \\
\text { Universitas Jambi } \\
\text { Jambi- Indonesia }\end{array}$ & $\begin{array}{l}\text { Hasil lompat jauh yang dicapai oleh siswa masih dalam kategori } \\
\text { kurang dikarenakan ada beberapa siswa yang tidak dapat } \\
\text { memenuhi standar hasil lompatan yang telah ditetapkan } \\
\text { besarannya. Peneliti membutuhkan beberapa langkah tepat untuk } \\
\text { dapat meningkatkan hasil lompat jauh siswa. Tujuan penelitian ini } \\
\text { adalah untuk mengetahui pengaruh kecepatan lari dengan hasil } \\
\text { lompat jauh, mengetahui pengaruh power otot tungkai terhadap } \\
\text { hasil lompat jauh dan pengaruh variasi latihan menggunakan media } \\
\text { box jump terhadap hasil lompat jauh siswa SMA Negeri } 9 \\
\text { Batanghari. Penelitian ini dilakukan dengan menggunakan } \\
\text { penelitian eksperimen Semu atau quasi experiment. Dimana pada } \\
\text { penelitian ini, akan diterapkan pada desain One Group Pre test } \\
\text { Post test. Populasi dalam penelitian ini adalah 100 orang, yang } \\
\text { kemudian dijadikan sampel adalah 26 orang, dengan cara } \\
\text { pengambilan sampel melalui quota sampling dan Purposive } \\
\text { sampling. Yang dijadikan sampel adalah siswa yang memiliki } \\
\text { tinggi } \pm 165 c m \text {. Hasil penelitian yang telah dilakukan oleh peneliti } \\
\text { rata-rata dari tes awal yaitu } 3.629 \text { dan rata-rata tes akhir adaldh } \\
\text { 3.945. Standar deviasi pre-test adalah 0.8541 dan standar deviasi } \\
\text { post-test adalah 0.6141. pengujian hipotesis dalam penelitian ini } \\
\text { menggunakan t-tes, dimana thitung adalah 7.191 dan t tabel } 2.060 \\
\text { dengan a = 0.05. Perbandingan harga antara t-hitung dan nilai } \\
\text { persentil dari tabel distribusi diperoleh t-hitung (7.19) > t-tabel } \\
\text { (2.060). Sehingga H0 ditolak dan Ha diterima Berdasarkan dengan } \\
\text { hasil penelitian dan pembahasan, dimana t-hitung (7.19) > t-tabel } \\
\text { (2.060) maka dapat disimpulkan bahwa terdapat pengaruh yang } \\
\text { signifikan antara kecepatan lari, power otot tungkai dan latihan } \\
\text { menggunakan box jump terhadap hasil lompat jauh siswa kelas X di } \\
\text { SMA Negeri } 9 \text { Batanghari } \\
\text { Kata Kunci : Kecepatan Lari, Power Otot Tungkai, Box Jump, } \\
\text { Lompat Jauh }\end{array}$ \\
\hline
\end{tabular}

This Indonesian Journal of Sport Science and Coaching is licensed under a CC BY-NC-SA (Creative Commons Attribution-ShareAlike 4.0 International License)

\section{PENDAHULUAN}

Bila dilihat dari arti atau istilah "Atletik" berasal dari bahasa Yunani yaitu Athlon atau Athlum yang berarti "lomba atau perlombaan atau pertandingan". Amerika dan sebagian Eropa dan Asia sering memakai istilah Atletik dengan Track and Field dan Negara Jerman memakai kata Leicht Athletik dan Negara Belanda memakai istilah Ahtletiek. Menurut Sukendro dan Ely Yuliawan (2019:1) Atletik merupakan gabungan dari beberapa jenis olahraga yang dapat dikelompokkan menjadi lari, lempar, dan lompat.

Atletik merupakan olahraga tertua dan juga merupakan induk atau ibu dari semua cabang olahraga. Karena gerakan-gerakan di dalam atletik merupakan dasar dari cabang olahraga-olahraga lain, seperti berjalan, berlari, melompat, dan melempar, ini semua telah dilakukan dalam aktivitas olahraga lain bahkan dalam kehidupan sehari-hari. Nomor lompat sebagai salah satu nomor yang dilombakan dalam kejuaraan atletik, merupakan nomor yang sangat menarik untuk dikaji. Menurut Eddy Purnomo (2007: 59) nomor lompat dibagi menjadi empat yaitu lompat 
jangkit, lompat tinggi, lompat tinggi galah dan lompat jauh. Menurut Eddy Purnomo (2007: 83) lompat jauh ditinjau dari gaya dibedakan menjadi 3 macam gaya yaitu gaya jongkok (tuck), berjalan diudara (walking in the air) dan melayang (hang style). Perlu diketahui bahwa dari ketiga gaya lompat jauh yang menyebabkan adanya perbedaan sebenarnya pada saat posisi badan di udara dan saat awalan, tumpuan dan pendaratan pada prinsipnya sama, namun di sekolah-sekolah lazim dilakukan adalah lompat jauh gaya jongkok. Tujuan utama dari lompat jauh yaitu mencapai lompatan yang sejauh-jauhya. Untuk mendapatkan hasil yang maksimal menurut Amad Komari (2007: 7), seseorang dalam menjalankan aktivitas atau gerak olahraga tergantung empat hal yaitu 1) fungsi organ tubuh (jantung, paru-paru, syaraf, otot, dan panca indra); 2) kemampuan dasar tubuh atau kemanpuan biomotorik, meliputi kekuatan, daya tahan, kecepatan, kelincahan, kelentukan, ketepatan, stamina, koordinasi, dan power; 3) sikap dasar tubuh yang baik; 4) semangat. Unsur-unsur tersebut harus selalu dibina dan dilatih agar dapat tumbuh dan berkembang sesuai dengan pola kekhususan gerak dari nomor atau cabang yang akan dipelajari.

Berdasarkan pengamatan peneliti selama mengajar di SMA Negeri 9 Batanghari, hasil lompat jauh yang dicapai oleh siswa masih dalam kategori kurang dikarenakan ada beberapa siswa yang tidak dapat memenuhi standar hasil lompatan yang telah ditetapkan besarannya. Sebagian besar siswa memiliki postur yang cukup mumpuni untuk melakukan lompat jauh gaya jongkok dengan baik, hal ini dilihat secara kasat mata oleh peneliti yang merasa kebanyakan dari siswa memiliki panjang tungkai yang proporsional. Namun timbul permasalahan tentang bagaimana pengaruh kecepatan lari, power otot tungkai dan penggunaan media latihan seperti balok rintangan terhadap hasil lompat jauh siswa.

Dari rangkaian uraian diatas penulis tertarik untuk membuktikan tentang pengaruh kecepatan lari, power otot tungkai dan variasi latihan menggunakan balok tumpuan terhadap hasil lompat jauh siswa kelas X SMA Negeri 9 Batanghari.

\section{METODE PENELITIAN}

Penelitian ini bertujuan untuk membuktikan pengaruh antara kecepatan lari $\left(\mathrm{X}_{1}\right)$, power otot tungkai $\left(\mathrm{X}_{2}\right)$, dan Variasi latihan $\left(\mathrm{X}_{3}\right)$ terhadap kemampuan lompat jauh $(Y)$. Maka penelitian ini termasuk jenis penelitian Eksperiment Semu (Quasi Eksperiment). Desain penelitian yang digunakan adalah One Group Pre-Test PostTest.

Menurut Arikunto, S (2006:130) yang dimaksud populasi adalah keseluruhan subjek penelitian. Sedangkan menurut Sugiyono (2006: 55) populasi adalah wilayah generalisasi yang terdiri atas objek atau subyek yang mempunyai kuantitas dan karakteristik tertentu yang ditetapkan oleh peneliti untuk dipelajari dan kemudian ditarik kesimpulannya Populasi yang dimaksud dalam penelitian ini adalah siswa kelas X SMA N Batanghari, yang terdiri dari 100 orang.

Sampel dalam penelitian ini diambil teknik quota sampel atau kuota sampel. Quota sampel adalah teknik sampling yang tidak mendasarkan diri pada strata atau daerah, tetapi mendasarkan diri pada jumlah yang sudah ditentukan. Peneliti menghubungi subjek yang menjadi penelitian tanpa menghiraukan strata atau daerah dengan catatan masih dalam populasi, biasanya subjek yang dihubungi adalah subjek yang mudah ditemui, yang terpenting disini adalah terpenuhi jumlah (quantum) yang telah ditetapkan. (Arikunto,1993:114).

Sampel dalam penelitian ini adalah sebanyak 26 siswa, yaitu siswa kelas $X$ SMA N 9 Batanghari. Penentu sampel menggunakan taraf signifikansi 0,05 atau taraf kesalahan $5 \%$.

Pengambilan sampel diambil dengan cara yang proposional yaitu dengan cara mengambil dari jumlah keseluruhan populasi yang ada dalam setiap kelas dengan 
kuota yang telah di tetapkan. Sampel tiap kelas diambil dengan pemenuhan kriteria tinggi tubuh yang telah di tetapkan oleh peneliti yaitu $\pm 165 \mathrm{~cm}$.

Teknik Pengumpulan Data dilakukan dengan mengukur hasil lompat jauh siswa di awal penelitian (pre-test) dan di akhir penelitian (post-test). Sedangkan treatment yang diberikan adalah Sprint, Standing Board Jump, dan variasi latihan menggunakan Box Jump.

Pengujian Normalitas menggunakan Saphiro Wilk dan uji hipotesis menggunakan ttes Menurut Singgih Santoso (2014:265), pedoman pengambilan keputusan dalam uji Paired Sample T-Test berdasarkan nilai signifikansi (Sig.) hasil output SPSS, adalah sebagai berikut:

1. Jika nilai Sig. (2tailed) $<0.05$, maka $\mathrm{HO}$ ditolak dan Ha diterima (ada perbedaan yang signifikan)

2. Jika nilai Sig. (2-tailed) $>0.05$, maka $\mathrm{HO}$ diterima dan Ha ditolak. (tidak ada perbedaan yang signifikan)

\section{HASIL PENELITIAN DAN PEMBAHASAN}

Berdasarkan uraian yang telah dikumpulkan sebelumnya, maka di dalam bab ini akan dijabarkan serta dianalisa pembahasan yang diperoleh dalam penelitian ini. Hasil penelitian ini akan digambarkan sesuai dengan tujuan dan hipotesis yang diajukan sebelumnya.

Tabel 1. Hasil Lompat Jauh

\begin{tabular}{ccccc}
\hline Keterangan & Rata-rata & SD & $\begin{array}{c}\text { Jumlah nilai } \\
\text { Maksimum }\end{array}$ & Jumlah Nilai Minimum \\
\hline Pre Test & 3.629 & 0.8541 & 5.15 & 2.21 \\
\hline Post Test & 3.945 & 0.6141 & 5.50 & 3.00
\end{tabular}

Dalam tes awal ini pada Tabel 1 di dapatkan hasil jumlah keseluruhan tes lompat jauh, dapat diketahui bahwa siswa yang berada dalam kategori Sangat Baik ada sebanyak 10 siswa, dalam kategori Baik sebanyak 8 siswa, 4 siswa berada dalam kategori cukup dan 4 siswa dalam kategori kurang. Untuk kategori sangat kurang tidak ada siswa yang berada di dalam kategori tersebut

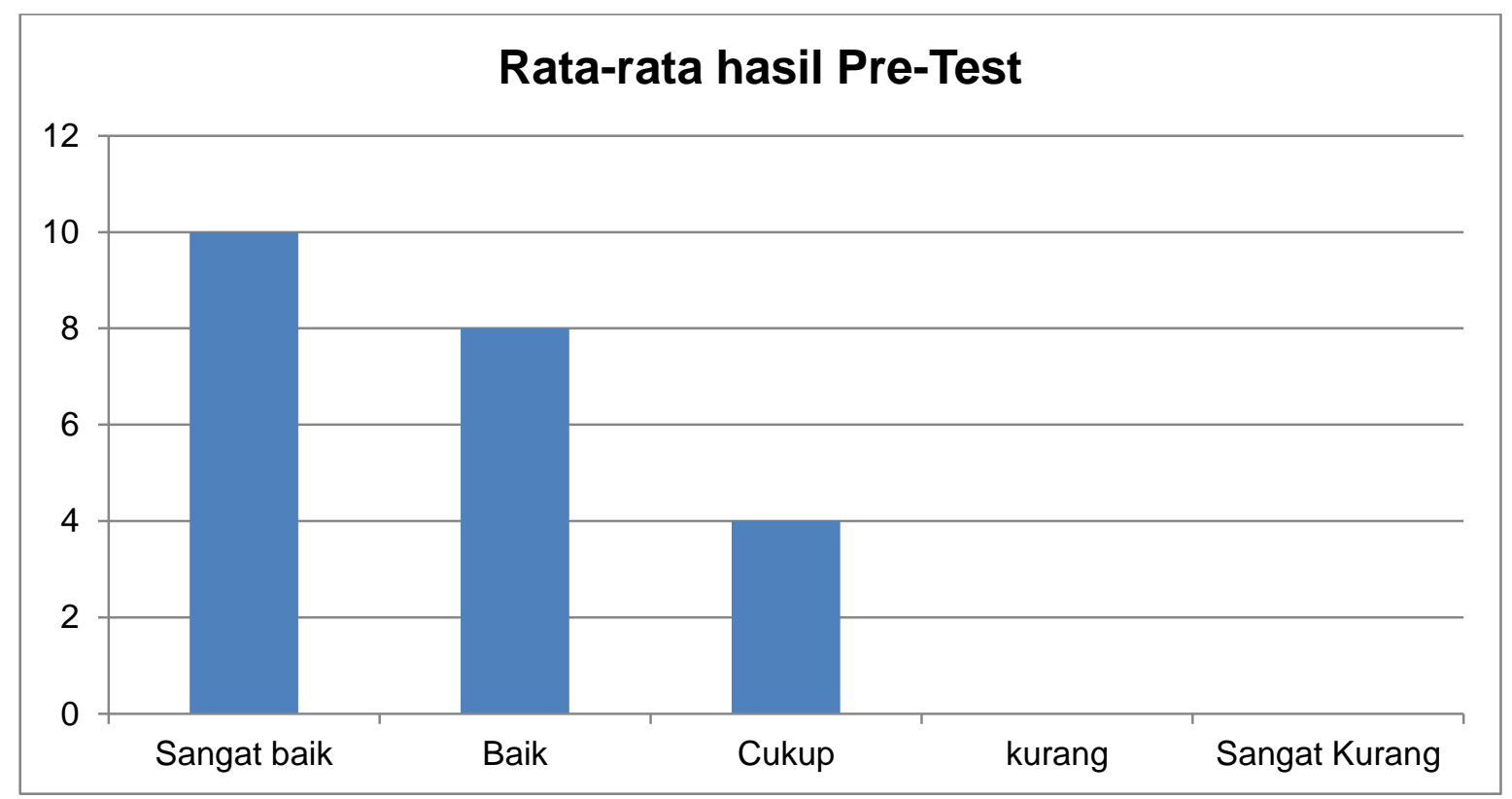

Gambar 1. Grafik Hasil Tes Awal Lompat Jauh 
Hasil lompat jauh dari siswa yang diteliti dalam penelitian ini merupakan perolehan dari uji coba yang dilakukan sebanyak 5 kali oleh siswa, dan diambil nilai perolehan yang paling tinggi pada saat Test Awal atau Pre Test.

Dapat pula di prosentase-kan, bahwa sebanyak 39\% siswa berada dalam kategori Sangat Baik, 31\% dalam kategori Baik, dan masing-masing 15\% untuk kategori Cukup dan Kurang. Walaupun dari hasil perolehan lompat jauh banyak yang berada dalam kategori sangat baik, namun beberapa siswa masih berada di kategori kurang. Hal inilah yang kemudian digunakan sebagai patokan oleh peneliti untuk dapat meningkatkan hasil lompat jauh siswa agar seluruh siswa mendapatkan hasil yang dapat setara baik putra, maupun putri. Penggunaan box lompat sebagai media bantu dalam lompat jauh juga dirasa tepat untuk dapat memberikan pengalaman tersendiri kepada siswa untuk melatih kemampuan dirinya pada saat melakukan lompat jauh dengan baik dan maksimal.

Berikut merupakan hasil tes akhir yang diperoleh bahwa hasil tes akhir lompat jauh Siswa di SMA Negeri 9 Batanghari yang meningkat dari pada hasil tes awal yang diperoleh siswa. Terbukti dengan perolehan prosentase Sangat Baik sebesar $65 \%$ dengan sebanyak 17 siswa yang meningkat performanya dalam lompat jauh. Sedangkan 9 siswa lainnya perolehan hasil lompat jauh dari tes awal dan tes akhir mereka yaitu di kategori baik, dengan prosentase yaitu 35\%.

Jika dilihat dari hasil lompat jauh siswa di SMA Negeri 9 Batanghari pada tes awal dengan perolehan kumulatif sebesar 94,36 dan perolehan ekumulatif tes akhir yaitu sebesar 99,92. Dengan perolehan tersebut terdapat peningkatan sebesar 5,56 poin. Hal ini dapat dilakukan dengan membandingkan tes akhir dan tes awal terhadap $t_{\text {hitung }}$ dalam taraf kepercayaan 0.05. Apabila $t_{\text {hitung }}$ lebih besar dari $t_{\text {tabel }}$ ini berarti adanya perbedaan yang berarti dan sebaliknya, apabila $t_{\text {hitung }}$ lebih kecil dari $t_{\text {tabel }}$ ini menandakan bahwa tidak ada perbedaan yang berarti (signifikan).

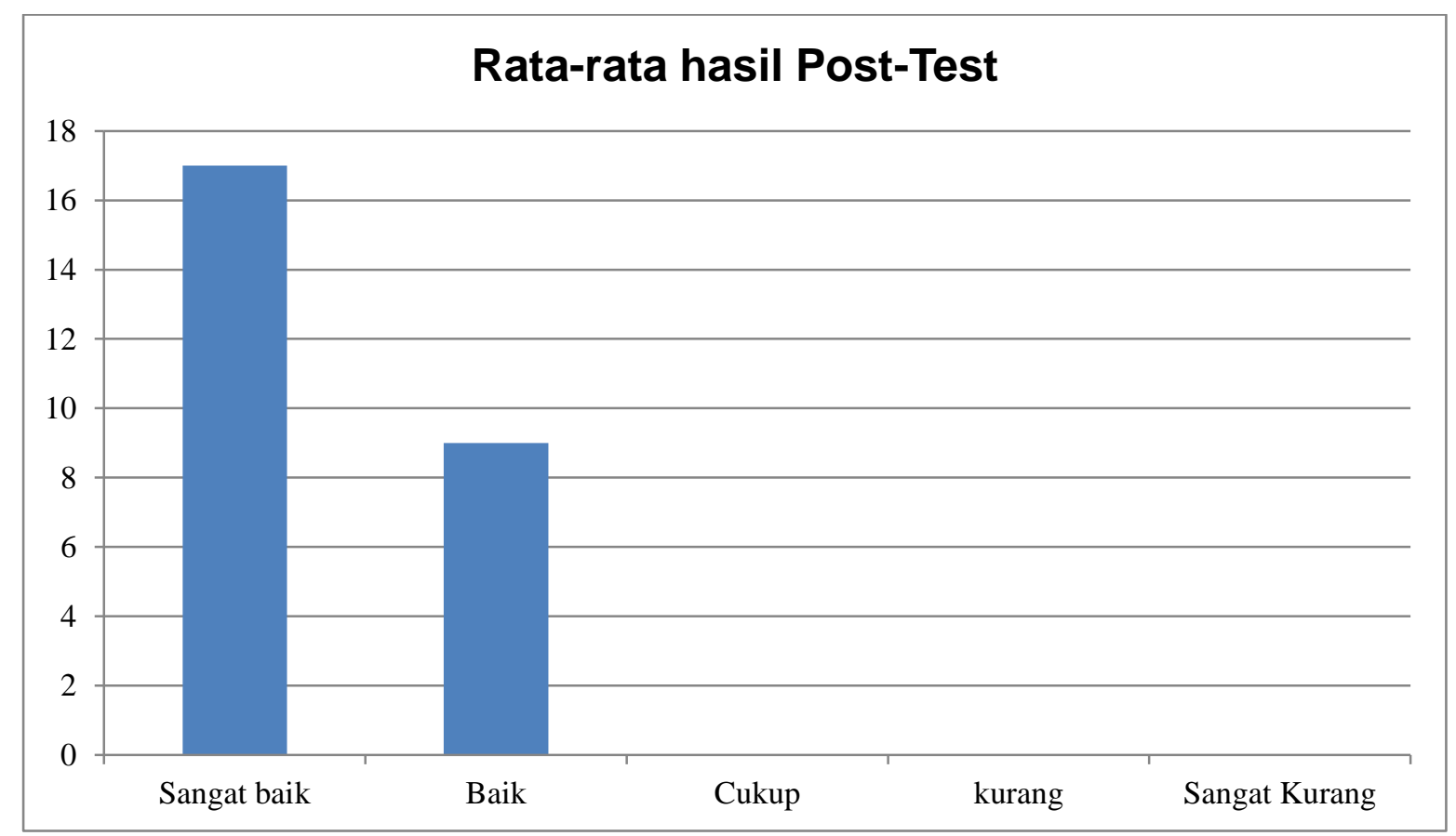

Gambar 2. Grafik Perolehan Tes Akhir Lompat Jauh

Analisis uji normalitas distribusi korvariabel dengan menggunakan latihan kecepatan, power otot tungkai dan media box jump data pre-test dan post-test dianalisis dengan statistik uji normalitas liliefors dengan taraf siginifikansi yang digunakan adalah $\alpha=0,05$. 
Tests of Normality

\begin{tabular}{|c|c|c|c|c|c|c|}
\hline & \multicolumn{3}{|c|}{ Kolmogorov-Smimov ${ }^{a}$} & \multicolumn{3}{|c|}{ Shapiro-Wilk } \\
\hline & Statistic & df & Sig. & Statistic & df & Sig. \\
\hline awal & .116 & 26 & $200^{\circ}$ & .963 & 26 & .457 \\
\hline akhir & .136 & 26 & $200^{\circ}$ & .962 & 26 & .431 \\
\hline
\end{tabular}

*. This is a lower bound of the true significance.

\section{a. Lilliefors Significance Correction}

Gambar 3 Uji Normalitas Saphiro Wilk Menggunakan SPSS

Penelitian ini menggunakan uji normalitas yang didistribusikan menggunakan SPSS. Uji normalitas yang digunakan adalah Uji Saphiro Wilk, hal ini dikarenakan jumlah sampel yang sedikit yaitu kurang dari 30 orang. Dasar pengambilan keputusan dari Uji Normalitas ini adalah :

a. jika nilai sig. $>0,05$, maka data penelitian berdistribusi normal

b. jika nilai sig. <0.05, maka data penelitian tidak berdistribusi normal

Berdasarkan hasil penelitian dan menyesuaikan dengan dasar pengambilan keputusan di atas, maka dapat disimpulkan bahwa Uji Normalitas data penelitian ini baik data awal dan data akhir adalah berdistribusi normal. Hal ini dikarenaka, nilai sig. data awal $0.457>0.05$ sehingga berdistribusi normal. Dan hasil perolehan pada tes akhir yaitu sig. data akhir $0.431>0.05$ juga berdistribusi normal.

Untuk menentukan apakah varian sampel homogeny atau tidak, maka dilakukan uji homogenitas dalam penelitian ini menggunakan SPSS.

Test of Homogeneity of Variances

\begin{tabular}{|c|c|c|c|c|c|}
\hline \multicolumn{6}{|c|}{ rest or nomioge } \\
\hline & & Levene Statistic & df1 & $d f 2$ & Sig. \\
\hline \multirow[t]{4}{*}{ hasil Iompat jauh } & Based on Mean & 3.754 & 1 & 50 & .058 \\
\hline & Based on Median & 3.692 & 1 & 50 & .060 \\
\hline & $\begin{array}{l}\text { Based on Median and with } \\
\text { adjusted df }\end{array}$ & 3.692 & 1 & 47.206 & .061 \\
\hline & Based on trimmed mean & 3.802 & 1 & 50 & .057 \\
\hline
\end{tabular}

Gambar. 4. Uji Homogenitas

Berdasarkan dengan table uji homogenitas di atas, sig. berdasarkan dengan ketiga data yang tertera dalah sebesar 0.057 lebih besar dari pada taraf signifkansi 0.05. jika kita masukkan ke dalam dasar pengambilan keputusan, yaitu:

a. jika nilai sig. $>0.05$, maka data penelitian bersifat homogen

b. jikan nilai sig. $<0.05$, maka data penelitian tidak bersifat homogen.

Data hasil penelitian yang telah dilakukan berdasarkan table yang di kotak dengan warna merah, yaitu nilai sig. $0.057>0.05$, sehingga data bersifat homogen.

Setelah dilakukan uji hipotesis dan uji normalitas, dilakukan uji hipotesis. Uji hipotesis digunakan untuk menjawab hipotesis awal yang telah dibuat. Dalam hipotesis awal yang di buat dalam penelitian ini yaitu :

HO : Tidak terdapat pengaruh yang signifikan antara kecepatan lari, power otot tungkai, dan latihan menggunakan Box Jump terhadap hasil lompat jauh siswa SMA Negeri 9 Batanghari

$\mathrm{Ha}$ : Terdapat pengaruh yang signifikan antara kecepatan lari, power otot tungkai, dan latihan menggunakan Box Jump terhadap hasil lompat jauh siswa SMA Negeri 9 Batanghari 
Hasil analisis yang diperoleh dari uji-t menunjukkan data sebagai berikut: $t_{\text {hitung }}$ adalah 7.191 dan $t_{\text {tabel }} 2.060$ dengan d.b $n-1$ (26 -1 $=25$ pada $\alpha=0.05$. 95\%) maka di bandingkan harga $t_{\text {hitung }}$ dengan harga $t_{\text {tabel. }}$. Perbandingan harga antara t-hitung dan nilai persentil dari tabel distribusi diperoleh t-hitung (7.19) > t-tabel (2.060). Ini berarti terdapat pengaruh antara kecepatan lari, power otot tungkai, dan latihan menggunakan balok rintang terhadap hasil lompat jauh siswa SMA Negeri 9 Batanghari.

Tabel 2. T-Test

\begin{tabular}{lccccc}
\hline \multicolumn{6}{c}{ Paired Samples Statistics } \\
\hline Pair 1 & Mean & N & Std. Deviation & Std. Error Mean \\
& pre test & 3.6292 & 26 & .85405 & .16749 \\
\cline { 2 - 6 } & post test & 4.0312 & 26 & .61414 & .12044 \\
\hline
\end{tabular}

Paired Samples Correlations

\begin{tabular}{lllrr}
\hline & & & Correlation & Sig. \\
\hline Pair 1 & pre test \& post test & 26 & .977 & .000 \\
\hline
\end{tabular}

Paired Samples Test

\begin{tabular}{|c|c|c|c|c|c|c|c|c|}
\hline & \multicolumn{5}{|c|}{ Paired Differences } & \multirow{3}{*}{$\mathrm{t}$} & \multirow[b]{3}{*}{ df } & \multirow{3}{*}{$\begin{array}{l}\text { Sig. (2- } \\
\text { tailed) }\end{array}$} \\
\hline & \multirow[b]{2}{*}{ Mean } & \multirow{2}{*}{$\begin{array}{c}\text { Std. } \\
\text { Deviation }\end{array}$} & \multirow{2}{*}{$\begin{array}{l}\text { Std. } \\
\text { Error } \\
\text { Mean }\end{array}$} & \multicolumn{2}{|c|}{$\begin{array}{l}95 \% \text { Confidence } \\
\text { Interval of the } \\
\text { Difference }\end{array}$} & & & \\
\hline & & & & Lower & Upper & & & \\
\hline $\begin{array}{r}\text { Pair } 1 \text { pre test - } \\
\text { post test }\end{array}$ & -.40192 & .28501 & .05590 & -.51704 & -.28680 & 7.191 & 25 & .000 \\
\hline
\end{tabular}

Perolehan yang di dapat pada tes awal tersebut yang menjadi acuan atau rujukan bagi peneliti untuk menjalankan program latihan dimana tujuan program latihan tersebut adalah untuk meningkatkan hasil lompat jauh siswa kelas X. usaha yang dilakukan oleh peneliti untuk dapat meningkatkan perolehan hasil lompat jauh siswa yaitu dengan menggunakan box jump untuk membantu siswa dalam tumpuan lompatan, lari sprint, dan standing board jump. Diharapkannya dengan beberapa latihan tersebut dapat meningkatkan hasil lompat jauh siswa. Hal ini dikarenakan dengan adanya latihan menggunakan box jump, lari sprint, dan standing board jump yang terpogram dan tersusun secara sistematis dapat membantu membiasakan sampel untuk melakukan gerakan yang ada pada saat melakukan lompat jauh dengan baik.

Tahapan treatment dilakukan sebanyak 16 kali pertemuan, dilakukan dengan porsi masing-masing sesuai dengan kemampuan siswa. Program yang di buat sudah disesuaikan dengan kemampuan siswa di kelas dan sekolah tersebut, namun tetap akan semakin meningkat untuk hasil akhir yang diinginkan yaitu meningkatnya hasil lompatan siswa dalam mata pelajaran lompat jauh. Siswa di berikan perlakuan yang sama, artinya tidak ada kelompok control disini. Hanya terdapat satu grup atau satu kelompok siswa, dimana pada satu kelompok siswa itu diberikan tes awal, perlakuan, dan tes akhir yang sama dan secara bersama-sama dilakukan.

Setelah siswa diberi perlakuan selama 16 kali pertemuan atau kali latihan, siswa diberikan tes akhir. Tujuan dari tes ahir ininadalah untuk mengetahui bagaimana hasil lompat jauh siswa Kelas $X$ setelah diberikan perlakuan, disinilah peneliti akan mengetahui apakah program yang disusun berdampak secara progresif atau tidak terhadap siswa.

\section{SIMPULAN}

Berdasarkan hal tersebut itulah, maka dapat disimpulkan bahwa sesuai dengan penelitian ini, kecepatan lari, power otot tungkai, dan latihan menggunakan 
box jump akan memberi dampak atau pengaruh yang signifikan terhadap hasil lompat jauh siswa kelas X di SMA Negeri 9 Batanghari. Hasil analisis yang diperoleh dari uji-t menunjukkan data sebagai berikut: $t_{\text {hitung }}$ adalah 7.191 dan $t_{\text {tabel }} 2.060$ dengan d.b n-1 (26 -1 =25 pada $\alpha=0.05$. 95\%) maka di bandingkan harga $t_{\text {hitung }}$ dengan harga $t_{\text {tabel. }}$. Perbandingan harga antara t-hitung dan nilai persentil dari tabel distribusi diperoleh t-hitung (7.19) > t-tabel (2.060). Ini berarti terdapat pengaruh antara kecepatan lari, power otot tungkai, dan latihan menggunakan balok rintang terhadap hasil lompat jauh siswa SMA Negeri 9 Batanghari.

\section{RUJUKAN}

Angga Firmansyah. (2017). Pengaruh Latihan Kelincahan dan Kecepatan terhadap Kemampuan Menggiring Bola Siswa SD 3 Merbau Mataran Lampung Selatan. Skripsi. Unila. Lampung

Arikunto, Suharsimi. (2002). Prosedur Penelitian.Yogyakarta: Rineka Cipta

Bahagia, Yoyo. (2005). “Meningkatkan Kecepatan Lari Sprint Dengan Model Latihan Panjang Langkah dan Frekuensi Langkah". Tesis. UPI:Bandung

Bosco,S James and Gudtafson,F William.(1983). Measurement and Evaluation in Phisical Education, Fitness, and Sport. United States of America

Gerry,Carr.(2003). Atletik untuk sekolah.Jakarta : PT.Raja Grasindo Persada

Gunter Bernhard.(1986). Atletik prinsip dasar latihan loncat tinggi, jauh, jangkit dan loncat galah. Dahara Prize. Semarang

Hasan, Iqbal. (2002). Metodologi Penelitian. Jakarta:Ghalia Indonesia

IAAF. (2000). Pedoman Mengajar Lari, lompat, lempar level 1. Jakarta: Development programme.

Indra S, Wira. (2006). Membangun Kebugaran Jasmani dan Kecerdasan Melalui Bermain. Jakarta: Depdiknas

Irianto, Djoko Pekik. (2004). Bugar dan sehat berolahraga.Yogyakarta: Andi Yogyakarta

Ismaryati. (2008). Tes Pengukuran Olahraga. Solo. LPP dan UPT UNS

Moura, N.A., \& Paula Moura, T.F. (2001). IAAF New Studies in Athletics (The IAAF Technical Quarterly). New York

Muhammad Ikbal. (2017). Pengaruh Panjang Tungkai, Daya Ledak Tungkai dan Motivasi Terhadap Kemampuan Lompat Jauh Siswa SMP Negeri 21 Makassar. Tesis. Universitas Negeri Makassar

Munar, H., \& Yuliawan, E. (2020). Upaya Meningkatkan Hasil Pembelajaran Gerak Dasar Lompat Melalui Pendekatan Bermain Lompat Lingkar Berwarna:(Efforts to Improve Learning Basic Learning Outcomes Through Approach to Playing Colored Levels). Indonesian Journal of Sport Science and Coaching, 2(1), 1-12.

Nur R, Hilda. (2013). Hubungan antara panjang tungkai, power otot tungkai dan kecepatan lari dengan kemmampuan lopat jauh gaya jongkok siswa putri kelas X SMA N 1 Prambanan Sleman, Yogyakarta. Skripsi. UNY

Priyatno, Dwi.(2011). Buku SPSS Analisis Statistika Data. Yogyakarta: Penerbit MediaKom.

Purnomo, Eddy. (2007). Pedoman Mengajar Dasar Gerak Atletik. FIK UNY

Purnomo, Eddy. (2011). Dasar-dasar Gerak Atletik. Alfamedia: Yogyakarta

Rahmat, Zikrur. (2015). Atletik Dasar dan Lanjutan. Aceh: STKIP Bina Bangsa

Sajoto, M. (1988). Pembinaan kondisi fisik dalam olahraga. Depdikbud. Jakarta

Setyawan, Eko Budi. (2014). Kontribusi Kelincahan dan Daya Ledak Otot Tungkai terhadap hasil lompat jauh gaya jongkok. Skripsi. UNESA. Surabaya

Sudjana. 2005. Metoda Statistika. Penerbit Tarsito. Bandung. 
Sugiyono. (2012). Metode Penelitian Pendidikan (Pendekatan Kuantitatif, Kualitatif, dan $R \& D$ ). Alfabeta. Bandung.

Sugiyono. (2013). Metode Penelitian Pendidikan (Pendekatan Kuantitatif, Kualitatif, dan R\&D).Alfabeta. Bandung.

Sugiyono.(2006). Statistika Untuk Penelitian.Bandung.:CVAlfabeta

Sukerdo, E. Yulliawan. (2019). Dasar-Dasar Atletik. Jambi: Salim Media Indonesia

Sutrisno. (2014). Buku Bahan Ajar Pendidikan Jasmani, Olahraga dan Kesehatan. Bogor :PPPPTK Penjas \& BK

TIM, Anatomi.(2003). Diktat Anatomi Manusia.Yogyakarta:FIK UNY

TIM, Fisiologi.(2009). Fisiologi Manusia.Yogyakarta: FIK UNY

U Jonath ,E Haag \& R. Krampel. (1987). Atletik I.Terjemah Soeparno.Jakarta: PT Rosda Jaya Putra

Yuliawan, E. (2015). PENGEMBANGAN MODEL PEMBELAJARAN LOMPAT JAUH PADA SISWA SEKOLAH DASAR. Cerdas Sifa Pendidikan, 4(1). 